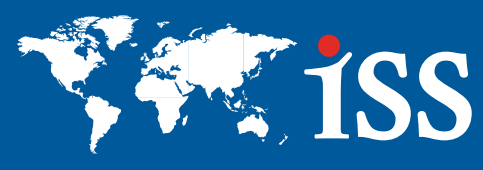

Institute of Social studies
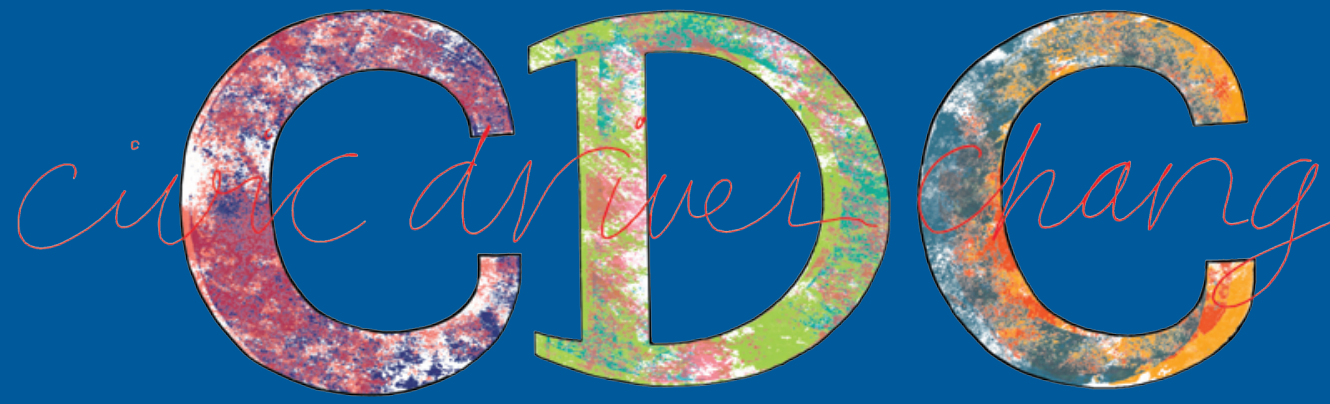

CIVIC DRIVEN CHANGE

\title{
A concise guide to the basics
}

\section{Kees Biekart \& Alan fowler}

The Hague - The Netherlands 


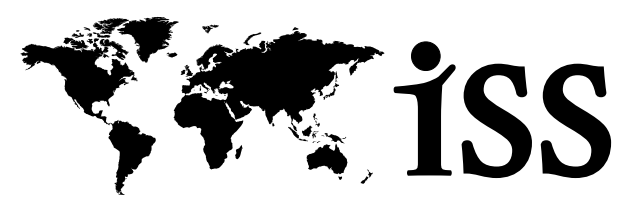

Institute of Social Studies

\section{CIVIC DRIVEN CHANGE: \\ A concise guide to the basics}

Kees Biekart \& Alan Fowler

April 2009 
The Civic-Driven Change (CDC) Initiative is a collective thinking and discussion effort to explore and communicate a perspective of change in societies that stems from citizens rather than states or markets. It was initiated by a group of Dutch private aid agencies (Hivos, Cordaid, ICCO Oxfam-Novib, SNV, IKV-Pax Christi, Context) and is co-ordinated and hosted by the Institute of Social Studies (ISS) in The Hague (Netherlands).

For further information: www.iss.nl/cdc.

\section{Published in April 2009 by}

Institute of Social Studies (ISS)

P.O. Box 29776

2502 LT The Hague

The Netherlands

Cover logo by Rutger Post/Inbeelding Amsterdam.

Text formatting by Karen Shaw, ISS

\section{CIVIC DRIVEN CHANGE: A concise guide to the basics}

The world is not working well. For more and more people, life is unfair and insecure. In fact, for years now the global future has looked less rather than more politically certain, financially stable and ecologically viable. This booklet introduces novel ideas about citizen efforts that can turn this alarming reality around. In doing so, it adds to debates about how the impasse of ineffective aided-development policies and practices can be broken.

It is clear that neither governments nor markets can bring solutions to the range of problems faced by societies everywhere. Yet, too often, as citizens, people do not take up or are allowed to play essential roles in creating answers to critical social and political ills and issues, such as countering poverty, discrimination, injustice, inequity, conflict, corruption and environmental unsustainability. It is time, therefore, for citizen's to reclaim their rightful place as agents of development, guiding how society evolves to what ends and on what terms.

The following pages start a new phase of a long-term process. Its goal is to bring to centre stage approaches to social problem solving that are driven by citizens, i.e., civic driven change (CDC). The first phase involved an international core group of practitioners and critical analysts, supported by an independent review process. During 2008, they worked on the question: what would a citizen-centred story of change in society look like? Initial results of this effort have been published as essays on the ISS website as well as in a book, and as policy papers (see References and Annex). All were presented and discussed at a seminar in The Hague, in October 2008, attended by about one hundred and eighty people. This second phase is directed at communicating results more widely. The task is to spread 
both knowledge of and stimulate discussion about civic action and drivers as a distinct approach to social change within and beyond the aided-development community.

This concise guide to CDC serves two key communication purposes. One is to cut through the detail to explain major characteristics of civic driven change as conceived by the core group. Second is to place CDC within the evidence, ideas and arguments generated by the critical commentary available so far as responses to a lead article in The Broker. These objectives will involve comparisons between CDC and current mainstream development thinking.

\section{Characteristics of Civic Driven Change}

The CDC framework can perhaps best be explained in terms of (1) location in existing debates, (2) a basic precondition and (3) five defining characteristics. In terms of location, this narrative of CDC draws together and positions itself within contentious discussions. These are enduring and unresolved debates about context-specific substance and 'optimal' relationships between:

- effective states and empowered citizens

- public and private spheres of life

- pro and anti-social values

- voters and political parties and processes

CDC offers a compelling lens which connects these debates in a novel way. It helps unpack and focus on deep causes of poverty and injustice which societies and agencies of aideddevelopment continue to grapple with.

The precondition is a situation where people enjoy basic civic rights and freedoms. Where these are denied, full exercise of citizenship becomes the real issue to be addressed, often by expanding the 'imaginative space of democracy' (Boyte, 2008a). In more open contexts, the advent of modern sovereignty casts citizenship as a fundamental, legitimizing relationship between a state and its population.

What citizenship means is written in a state's Constitution. But, in practice, being a citizen has a wide range of (in)significance for people's identity and self-understanding. Nevertheless, all constitutions regulate the extent of people's freedoms towards each other and towards the state. In these relationships, CDC is premised on a quality of citizenship which is 'civic'. That is, citizens behaving in ways which respect differences between people, allied to a concern for the whole of society and its natural environment.

CDC operates in terms of rights and obligations. These can function both towards and within institutions. For example, people have rights in relation to criminal charges - they are innocent before proven guilty. But they also have obligations towards fellow workers or employers: such as not to sexually harass or racially abuse.

A CDC view of society also questions any statement about a 'natural' boundary between what is public and what is private. Such ideas are often projected through political dialogue into the public mind and people's world view. In other words, CDC confronts divisions between what is a 'shared' issue and what is not. For example, if private banks are 'too big to fail' because the economy and society would 'collapse' along with them, who, then, should they belong to? Similarly, it questions the principle that, through corporate taxation, the public takes on responsibility for 'externalised' environmental damage they cause. CDC is at the forefront of the public/private debate, where the idea of a 'global commons' reinforces attention to interdependence on one planet. 
A civic-driven change approach does not simply accept historically evolved rules of the game within society as prescribed or as having no alternative. Rules and social formations can be unravelled and rewoven as part of a change agenda. This process happened with the civic-driven reconfiguring of society in post-Soviet east and central Europe. Mass, self-organised and self-propelled assertiveness of China's farmers to change the Communist Party's policy on land ownership is a recent example of civic agency. The efforts (and risks) carried by the Chinese middle class and intellectuals to establish and sign up to Charter 08 for greater political freedoms are another. Some might even argue that the recent election of Barack Obama signals a civic-driven re-constitution of the politics of race in America because it was founded on a tradition of community self-organising, 'public work' and culturally appropriate practices for collective action (Boyte 2008b).

\section{Language}

Understanding $C D C$ requires a particular language associated with a set of key concepts. The terms and meanings shown in the box are particularly important.

CDC does not rely on the 'three Ps' that are central to the theory and practice of mainstream aided change. These are Projects, Participation and Partnership. These terms serve and reinforce an institutionalised way of understanding socio-political processes, typically with government in the lead and in control. Over time, this terminology has come to both anticipate and label a 'harmony' model of change. That is, all types of change in society can be negotiated, creating win-win situations for all parties. In turn, this view assumes and requires the 'civility' of everyone involved. Apparently, economic exploitation, corruption, state immunity and abuse of official positions are never in play.

In distinction, the CDC framing rests more on assertive selforganisation. People negotiate countless forms of collaboration. Asymmetries in power and grappling with associated contention are common place. This process is itself valued as an organic form of socio-political capacitation, or civic selfempowerment.

\section{Box 1. CDC Language}

Development is bringing about change in the 'political project 'pursued by a society.

(Deep) democracy is a condition where the polity effectively exert a shared influence over those with public authority and holds them to account.

Agency is the application of a person's energy towards realising an imagined future.

Civic behaviour is pro-social and premised on exercising the rights and obligations of citizenship that contribute to public benefit.

Civic agency is the self-willed action of people to create the society they individually imagine and collectively want. It involves empowerment in crafting and navigating political space.

collaboration is, with power in the foreground, about negotiating and forming relationships that further civic agency.

civic self-organisation is a capacity-enhancing ability to produce public value, often though public works.

\section{The basic elements of civic-driven change}

The broad characteristics of civic driven change arise from many social and political elements. They can be grouped in 
many ways. Context is important because it will usually determine which way of bringing them together makes most sense. The grouping below is meant to be illustrative with no specific situation or history in mind. Though somewhat stereotypical, mainstream development thinking is described in order to focus comparative attention on CDC perspectives.

\section{(a) Socio-political relationships}

Mainstream aided development thinking typically takes (Western-style) citizenship for granted. There is an implicit modelling along the lines of what donors want to be the case, but without explicit attention to the political philosophy on which rights and obligations are based. For example, what is the balance - if any - between loyalty to the nation and freedom to criticise authority? The centrality of the state as development actor is also simply assumed. Not to do so would invite problems about sovereignty.

\section{A CDC approach:}

- Starts with the centrality of citizenship as a political relationship between a state and its population: full legitimacy of the former requires informed active engagement by the latter.

- Pays careful attention to the power and interests hidden within the language and discourse employed by whom.

- Recognises that societies are continually evolving as 'political projects' - that is, they are driven by the beliefs, interests, desires and aspirations, world views and representations of what society should be which guide political action. People's imagination matters.

(b) Trust in people's experience and knowledge

Mainstream aided development relies on (external) technical experts for virtually everything it engages with. The ritual of donor mission after mission is a well known syndrome. Associated is a prescriptive formulaic 'three sector' institutional framing and explanation of social structure, roles and responsibilities. The premise of 'participation' is that professional views are best. People can take part in change processes defined by others. Citizen's experience and knowledge is not necessarily ignored, but it is scripted into a pre-defined progression to be financed.

\section{A CDC approach:}

- Gives primacy to civic agency - people's action in shaping society - which happens in all walks of life.

- Challenges institutional prescriptiveness and civic irresponsibility of any sector or actor.

- Opens up to multiple types of knowledge and sites of knowledge-making. Priority is not accorded to external specialists or 'disembodied' science. This does not mean that people are always 'wise' or right in their understandings, but that they need to organise and find this out for themselves in order to 'self-capacitate'.

(c) Contention in values, measures and processes: Where do outsider 'developers' belong?

With varying degrees of sensitivity to what exists, mainstream development brings a baggage of norms, values and metrics tied to resources and local abilities to use them well. This combination can cause serious dilemmas when the process of change required cannot be 'harmonious'. For example, civic resistance is required to remove corrupt 'winners' and diverters of aid finance. Similarly, measures made meaningful for mainstream aid have, eventually, to translate into money and return on investment. Other measures do not carry as much weight, even if they do so locally. Finally, the system of aid relationships rests on a structural asymmetry in terms of risks 
of change. Outsiders are seldom held to account locally and can withdraw when change gets rough. Insiders have to cope as best they can with what remains of good intentions gone wrong.

\section{A CDC approach:}

- Works with the fact that change in society is normative and is as often conflictual as it is collaborative. Attaining democracy often means facing the dilemma that civic ends sometimes call for uncivic means, such as civil disobedience.

- Is sensitive to who carries risk, with caution about the role of outsiders in bringing about change to, for or with others: value-imposition and 'expertised' disempowerment are too frequent outcomes.

(d) Beyond party-political systems

Ostensibly, mainstream aid respects the principle of noninterference in the internal affairs of a country. Adherence to this principle is most sensitive when party-politics is involved. Zimbabwe today is a case in point. But mainstream aided development ignores the deeper issue of the extent to which party politics is the most appropriate instrument to ensure popular control over those in authority. There are many signs that this mechanism is past its sell-by date as a means to distribute power and enforce accountability for its use.

A CDC approach:

- Pins down context-specific historical processes of power accumulation that have marginalised the polity, typically recasting citizenship in terms of clients to be served by privatising rights, public space and fulfilment of government obligations.
- Responds to the failure of party-based politics exhibited in voter apathy, tied to electoral manipulation and widespread mistrust in today's political systems and leaders. Democracy as currently practiced is being eroded from within and will not self-reform. Local citizen action is a critical starting point for reform to happen.

- Knows that media and communication matter. Information - its substance and source - is a vital factor in shaping civic agency. Understanding origin, control and 'spin' are fundamental.

(e) CDC has a different perspective on equity

As an almost an axiomatic philosophy, mainstream development relies on equity of economic opportunity as the engine of social change. Empowerment is typically viewed in terms of expanding people's choice through economic gains to get above a poverty line set in financial terms. Other benefits flow from this gain. Examples are increasing capabilities to access good and services and to engage in market transaction from a stronger position.

A CDC approach:

- CDC differs in this basic premise. Development - aided or otherwise - is not defined by economic measures, but as a political project pursued by all parts of a society.

- Its axiom is that what is needed to reduce poverty and marginalisation is equity of political agency - that is a condition where all citizens have the capabilities needed to co-determine the life and society they want in its many dimensions and possibilities, including the leadership and economic model a country chooses.

- This principle reframes the metrics of (un)aided development processes and intended outcomes. 
Lurking behind this summary are many familiar and less familiar stories and theories about how societies work and alter over time. This leads to an obvious first reaction: what's new? And, what is missing? One way of addressing this type of response is to reflect on the comments posted on The Broker and the summary overview (Verkoren, 2008). This publication provides a valuable open forum for debate which has been actively taken up in commentaries that continue to grow.

By its nature and timing, The Broker piece (Bieckman, 2008) was a compressed and early summary of both the process and substance of the group's collective reflection. And, of course, there are many other stories and angles. For example, the economics of CDC is not covered: a gap that needs to be addressed. And, inevitably, the article "Deepening Democracy" could not capture the whole body of ideas, experiences and real life cases that made up the CDC story. One outcome is interpretations of what CDC is about that may not correspond with what is presented. Another is the impression of CDC as an abstraction. In other words, it is not grounded in reflections on practical experience - which it is. However, comments which reflect such outcomes are important. They communicate critical ideas and feedback that merit a thoughtful response, not to defend CDC, but to help clarify and test its value for further reflection and action.

\section{The novelty of CDC}

'What is really new about CDC?' This reaction reappears in debates following the presentation of the CDC essays. In one way, the question is justified. But when uncommon avenues and ideas are being explored, it represents only one logic among many. Responding to this question also requires caution. Why? Because there seems to be a pressing need within
NGO circles to always come up with something 'new'. As if 'new' always implies an improvement and a step forward. Perhaps this stance results from the push for constant innovation in aid policies as signs of progress and learning because the evidence does not tell its own unequivocal, compelling story.

Rather than 'new' we argue that CDC offers a different - potentially inspiring - perspective on recurrent issues that aid agencies are grappling with. This perspective is not necessarily 'new' in terms of innovating a particular practice or strategy. Instead, CDC can offer a refreshing angle into examining persistent issues or enduring 'thorns in agencies' flesh'. From recent discussions we suggest seven areas where $\mathrm{CDC}$ offers interestingly 'different' perspectives.

(1) Shifting the focus from 'civil society' to 'civic action': For many years, civil society has been used as a concept in aid discourse to differentiate between governmental and non-governmental channels of aid delivery and to locate the sphere in which partner organisations and networks operate. However, increasingly there has been a tendency to embrace 'civil society' not only as 'the good guys' but also as an actor for change in and of itself, a stance that causes much confusion. To begin with, civil society cannot be perceived as a single actor or mono-purposeful entity. In most definitions, civil society is characterized by a variety of societal actors representing different - and often opposing - world views and interests. An extreme example of these opposing interests is the occurrence of anti-democratic or 'uncivil' actors in civil society, such as neo-Nazi's, criminal cartels and intolerant, anti-social groupings. Civic-driven change puts the 'civic' element central in its analysis. It makes explicit the need to recognise and counter change that could be characterized as 'uncivic'. Given the conventional approach to civic society as an ostensibly benign 
location providing socially valuable functions, this can be regarded as a significant clarification.

(2) $C D C$ rearticulates the centrality of citizens and citizenship: A second area where CDC offers a renewed perspective is the centrality of citizens as key actors in change processes. Citizens are entitled to a range of political and civil rights with associated (moral) obligations that are central to the understanding of citizenship. This assertion adds considerably to their 'contained' roles of being mere voters, inhabitants of a geographical space, or consumers of products and services. CDC reemphasizes the importance of citizenship and puts citizens back in as the primary members of the polity. Of course, citizens are different from 'civic actors'. The latter is a wider concept including organizations, movements and networks that manifest 'civic agency'. But citizens also have 'civic agency' and are certainly part of the family of 'civic actors'. This perspective challenges positions in debates where the individual role of citizens is often subordinated to the interests of social institutions, (umbrella) organizations and their representatives.

(3) CDC is a tiered, cross-boundary viewpoint on society and change: A third area where a civic-driven framework can help to inform new perspectives on change is the important observation that civic action is not limited to - nor oriented at - civil society alone. Some commentators argue that CDC is 'overloading the arena of civil society with too much responsibility'. The CDC essays actually argue the opposite. Civic action - as well as uncivil action - takes place in all possible arenas of social life: in civil society as well as in politics, in markets as well as in the realm of the household. After all, public servants have civic agency, so do employees, consumers, parents and children, voters and citizens. Planned or otherwise, people's actions operate simultaneously, habitually and strategically in all these spheres. As commentators note, the co-creation of public life is something that often goes beyond 'public action' and emerges from the private sphere of the family, in terms of world view, education, gender roles and more personal aspects of socialization.

From the standpoint of citizenship and CDC, the classical sectoral approach in which society is split up into three sectoral 'balloons' or institutional domains, further divided by public and private spheres, is too simple. This framework is an increasingly distorting approximation of reality. The nature of citizenship pervades all spheres of society. Social innovation and social entrepreneurship continue to blur institutional boundaries. And there are growing tiers and density of connections - where 'globalized' means 'many localities joined up'. These and other processes that shift human relations and the power differences within them call for a fundamental revision to the schemas used to comprehend (interdependent) social change. $\mathrm{CDC}$ is one lens for doing so.

(4) CDC does not take 'aided change' as a starting point: This position seems to be a controversial feature of the CDC approach in terms of its argument that social change will not essentially depend on the initiatives of (non-governmental) aid agencies. It is civic actors who decide about structural and enduring changes in their society. At best, aid agencies with good intentions and practices that - at a minimum 'do no harm' - can play at most a facilitating role. This 'proportionality and humility' point is not original. The new element is that this 'thinking project' has been initiated by some key Dutch aid agencies who accept that their - or their partner organisations' - future existence is no longer the point of departure for strategizing. This major milestone makes a new and fresh approach possible to what we have called 'aided change', which too often turns out to be a less sustainable type of social change. 
(5) CDC primarily focuses on the process of social change, rather than only on the social actors themselves: This is a complex point, which can be easily misunderstood. CDC puts citizens central into processes of social change. One result is to emphasise important tools such as empowerment, self-organisation, popular education and cultural organising. However, mainstream aided change over the years has increasingly emphasised an 'implementation logic'. This stance focuses mainly on the particularities of change-driving actors (capacity building, accountability, sustainability, etc). The implication has been a shift away from what is actually being achieved. In many contexts, the corresponding investment in the creation of NGO bureaucracies hinders social change rather than triggering it. That is why a CDC approach tends to focus more on the outcomes of empowering processes (social change) rather than mainly on the roles and capacities of its key actors. The CDC framework certainly requires more elaboration in order to cope with particular contexts and value-systems. But the essential shift of effort is to explore more systematically the eventual results of transformative change that benefit the previously excluded and marginalized.

(6) CDC has the potential to link local to global change: Another criticism has been that the CDC framework starts from the assumption that local change will automatically generate change at the global level. At least, it has not been specified how the two are linked. From a CDC perspective transformative change always implies changes taking place in complementary - but seldom synchronized - ways at multiple sociopolitical scales and tiers. But since CDC takes a perspective of citizen-led change, this obviously is a bottom-up process that is articulated and linked at higher levels. This may be classed as 'romantic'. Which is, indeed, a positive way of looking at it. But, everything 'global' has some form of local manifestation. A CDC approach stresses the fact that local processes of social change will have to engage with each other in order to achieve larger transformations. This point is illustrated as much by Obama's presidential campaign in the 21st century, as it is by the campaigns to abolish slavery and struggles for women's right to vote in the 19th and 20th centuries.

(7) CDC actually does not pretend to be 'new': The criticism that the CDC approach is 'too academic' and that the authors lack relationships with day-to-day reality is simply unfounded. The CDC perspective was elaborated on the basis of reflection on practical engagement and real life cases. But, indeed, many more experiences or 'CDC narratives' will have to be analysed in order to really work towards an academic 'theory' of civicdriven change. What is on paper so far are a range of pointers and ideas worked out in, and emerging from, individual essays. There is no pretension to be a new paradigm of social change. However, it can be argued that a new element signalled by the various comments is a valued recognition of a necessary effort to explore the dynamics of social change that do not initially stem from within an 'aid-driven box'.

Overall, we are pleased that an intended debate is coming on stream and look forward to further initiatives and exchanges in the spirit of critical innovation. A few concluding observations may help stimulate thinking about ways ahead.

\section{CDC follow-up activities}

The CDC initiative is not alone. As the published materials note, other institutions are tackling similar issues from complementary angles and different scales of enquiry. It may therefore be the moment to bring together these various activities and their lessons in a knowledge-exchange. 
The CDC initiative is a work in progress. We think that the following elements would merit more detailed work in the period ahead.

- Tracing the threads of CDC to previous development theories and placing it and them in the 21st Century.

- Examining more and more experiences through a CDC lens to test both its ideas and substance. Does CDC improve our understanding of how social change occurs and to whose benefit? And, is it practice-relevant?

- Undertaking a thorough look at what a CDC approach implies in terms of existing strategies, policies and practices of public aid agencies. To help in grounding - perhaps different work contexts could be used - from autocratic governance and conflict situations through to stable settings where civic agency is alive and well.

- Understanding the system-wide and organisational processes involved in 'interrogating' novel ideas like CDC. How and why do aid-based institutions respond in the way they do when an innovation appears on the landscape? The value of such an effort would be to help leaders of organisational change learn from the experience of others. Given future world scenarios that are likely to require a capability for agility and continuous adaptability, CDC might be a useful 'guinea pig'.

An overarching guide to these types of initiatives is to promote ways in which a 1,001 CDC stories can be told and shared, including those that are uncivic. We hope that the characteristics of a CDC lens generate new knowledge from reflections on existing practices and cases; that stories are told which cross and connect institutional boundaries. And which increase stories which provide access to and learning about unaided actions by citizens in all walks of life that are dedicated to solving the social, ecological and other problems that are making the world unjust, insecure and unwell. 


\section{Reference Materials}

Bieckmann, F., 2008, "Special Report: Deepening Democracy", The Broker, No. 7, August.

Boyte, H, 2008a, "Civic Driven Change and Developmental Democracy", in Fowler, A. and Biekart, K. (eds), Civic Driven Change: Citizen's Imagination in Action, pp. 119-138, Institute of Social Studies, The Hague.

Boyte, H., 2008b, "Civic Driven Change: Organizing Civic Action", ISS-CDC Policy Brief, No. 3, Institute of Social Studies, The Hague.

Fowler, A. and Biekart, K., 2008a, "Introducing Civic Driven Change", ISS-CDC Policy Brief, No. 1, Institute of Social Studies, the Hague.

Fowler, A. and Biekart, K., 2008b, "Civic Driven Change and Aided Development”, ISS-CDC Policy Brief, No. 2, Institute of Social Studies, The Hague.

Fowler, A. and Biekart, K. (eds), 2008, Civic Driven Change: Citizen's Imagination in Action, Institute of Social Studies, The Hague.

Konijn, P. and Ham, A. van der, 2008, "Civic Driven Change - A New Impetus to the Debate", ISS-CDC Policy Brief, No. 5, Institute of Social Studies, The Hague.

Mathie, A. and Cunningham, G., 2008, From Clients to Citizens: Communities Changing the Course of Their Own Development, Intermediate Technology, Rugby.

Rai, S., 2008b, "Civic Driven Change: Facing Risk", ISS-CDC Policy Brief, No. 4, Institute of Social Studies, The Hague.

Verkoren, W., 2008, "Debating Civic Driven Change: People's Power", The Broker, No. 10, December.

\section{Useful sites}

http://www.iss.nl/cdc

http://www.ids.ac.uk/citizenshipdrc/

http://democracy.carnegieuktrust.org.uk/civil_society

http://www.thebrokeronline.eu

http://www.oxfam.org/en/policy/from_poverty_to_power 


\section{Annex}

\section{Contents of Civic Driven Change: Citizen's Imagination in Action}

1. Civic-Driven Change: Citizen's Imagination in Action Alan Fowler \& Kees Biekart

2. Civic-Driven Change and Political Projects Evelina Dagnino

3. Civic-Driven Change: Spirituality, Religion and Faith Philomena Mwaura

4. Six Degrees and Butterflies: Communication, Citizenship and Change

Alfonso Gumucio-Dagron

5. Civic-Driven Change: Of the Law and the Role of Outsiders Nilda Bullain

6. Civic Driven Change: Opportunities and Costs Shirin Rai

7. Civic Driven Change and Developmental Democracy Harry Boyte

8. Civic Driven Change for Deepening Democracy Rajesh Tandon

9. Global Civic-Driven Democratization as Political Agency Teivo Teivainen

10. Civic Driven Change: Implications for Aided Development Alan Fowler \& Kees Biekart

These essays can be downloaded free of charge at: www.iss.nl| cdc

\section{About the authors}

Dr Kees Biekart (Netherlands) is a senior lecturer in political sociology at the Institute of Social Studies (ISS). Before coming to ISS he worked as a research co-ordinator at the Transnational Institute (TNI) in Amsterdam. He completed his $\mathrm{PhD}$ in Political Science at the University of Amsterdam. His research has focused on processes of social change involving NGOs, social movements, civil society and foreign aid, in particular in relation to Latin America. He is a co-editor of the journal Development and Change.

Dr Alan Fowler (South Africa) is an affiliate professor at the Institute of Social Studies. He has been active for many years in international development as an organizational adviser as well as writing about, publishing and researching the aid system with a special focus on civil society. His wide institutional experience has included roles as a Ford Foundation programme officer and World Bank Visiting Fellow. He completed his DPhil at the Institute of Development Studies, University of Sussex. Since the mid-seventies Alan has worked and lived in Africa and Asia and is now resident in South Africa. 


\section{Address}

Institute of Social Studies

P.O. Box 29776

2502 LT The Hague

Location:

Kortenaerkade 12

2518 AX The Hague

The Netherlands

Telephone: +31 704260419

Fax: +31 4260759

E-Mail: info@iss.nl

ISS Homepage: www.iss.nl 